\title{
Some helpful sources for prospective authors in Asia Pacific Journal of Management
}

\author{
David Ahlstrom
}

Published online: 8 October 2011

(C) Springer Science+Business Media, LLC 2011

At Asia Pacific Journal of Management (APJM) we receive many queries from prospective authors about publishing in $A P J M$. In response, we have been running a series of articles that aim to assist prospective authors in that endeavor. ${ }^{1}$ This paper briefly summarizes those $A P J M$ articles along with some other helpful publications that have appeared elsewhere in the management literature so authors will have a quick reference to this work (cf. Ahlstrom, 2011b). ${ }^{2}$

\section{Aims and scope}

APJM has published three articles that have discussed the journal's aims and scope at some level (Ahlstrom, 2010a, 2010b, 2011a), one of which was primarily dedicated to that topic (Ahlstrom, 2011a). This is important for prospective authors

\footnotetext{
${ }^{1}$ The Academy of Management Journal is also running a series of seven editorial articles on publishing in $A M J$ in 2011 and 2012 that authors should find very helpful (e.g., Colquitt \& George, 2011).

${ }^{2}$ It is impossible to mention even a small percentage of the many works helpful to management and organization scholars in their research. For some helpful instructions, review articles, and summaries of the research design literatures see Bono and McNamara (2011), Creswell (2008), Cummings and Frost (1985, 1995), Huff (1999, 2008), Ismail and Ford (2010), Kilduff (2007), Machi and McEvoy (2008), and Van de Ven (2007).
}

The Asia Pacific Journal of Management would like to announce our first impact factor as published by Thomson Reuters in their Social Sciences Citation Index. That impact factor for 2010 (the most recent year) was 3.36, placing APJM in the top 18 management journals, just after the Strategic Management Journal and Personnel Psychology. Thanks are due to all of APJM's Senior Editors, the Editorial Advisory and Review Boards, our reviewers, and of course all of our authors for their hard work on behalf of the journal. Thanks also go to our former Editors-in-Chief Mike Peng of UT-Dallas, and Andrew Delios and Kulwant Singh of the National University of Singapore for all their previous (and continuing) efforts on behalf of the journal. APJM would also like to recognize the hard work of our managing and copy editors, Rachel (Rae) Pinkham in Texas, USA, Saraswathi (Sara) Ramaswamy in Chennai, India, and Jurgen Torres, in Manila, Philippines. Thanks also go out to Dean T.J. Wong of The Chinese University of Hong Kong, Faculty of Business, as well as Professor Garry Bruton and Dean Homer Erekson, of the Neeley School of Business, Texas Christian University for their help and financial backing of APJM.

D. Ahlstrom $(\bowtie)$

Department of Management, The Chinese University of Hong Kong, Shatin, NT, Hong Kong e-mail: ahlstrom@baf.msmail.cuhk.edu.hk 
to understand as $A P J M$ is still receiving a significant number of submissions that have little to do with theory in management and organizations, such as papers on using the Balanced Scorecard or describing the activities of a single firm. These topics are certainly interesting but prospective authors need to recognize that APJM (like most academic management journals) does not publish "how to" articles directed mainly at managers and supervisors (Ahlstrom, 2010c; Kilduff, 2007). Rather, we encourage papers that ask (and answer) research questions addressing or improving management theory, that is, questions first and foremost of interest to management researchers (e.g., Christensen, 2006; Christensen \& Carlile, 2009).

Research published in $A P J M$ often includes the reporting of interesting conceptual or empirical results that are theory-driven, contribute to management theory, and are (potentially) useful to managers and organizations (Ahlstrom, 2010b; Fang, 2010; Stevens \& Cooper, 2010). Textbook-type chapters and articles geared more for business magazines, or research that contributes primarily to disciplines other than management, such as economics, marketing and consumer behavior, accounting and finance do not fit the aims and scope of APJM (see Ahlstrom, 2010c, 2011a). Case studies that build and clarify theory are certainly welcome. But cases that simply explain something that is well understood by management academics and are geared more for teaching purposes should be submitted to journals that specialize in classroom-oriented case research such as the Asian Case Research Journal. For more information on case study research see Flyvbjerg (2006), Siggelkow (2007), and Yin (2009), and on building theory from cases, see Christensen and Carlile (2009), Eisenhardt and Graebner (2007), and Suddaby (2006).

\section{Introductions and research questions}

Many papers' chances are hurt by having a weak introduction and a confusing (or no) research question (Ahlstrom, 2010b; Huff, 1999). For further explanation on introductions and research questions, prospective authors should refer to my editorial articles (Ahlstrom, 2010a, 2010b) which give several examples and summarize some other helpful works in this area. ${ }^{3}$ One such work is Scott Shane's (2008) interesting book Illusions of Entrepreneurship, which uses a research question to head each chapter, such as Chapter 3: Who Becomes an Entrepreneur? Other works include review and commentary articles that summarize and discuss potential research questions and future research in a particular area (e.g., Bhagat, McDevitt, \& McDevitt, 2010; Fang, 2010; Hayton, George, \& Zahra, 2002; Locke \& Latham, 2009). For example, the Hayton et al. (2002) paper in Entrepreneurship: Theory and Practice has a long table listing articles on culture and entrepreneurship, with their research questions and findings.

\section{On theory}

Some work that is helpful in terms of defining theory and how to test and improve it include Christensen and Raynor (2003), Cummings and Frost (1985, 1995), and

\footnotetext{
${ }^{3}$ For some additional good examples of introductions see Carney et al. (2009) and Meyer et al. (2009).
} 
Sutton and Staw (1995). For additional examples of theory building in the organizational research field see Abbott (2004), Eisenhardt and Graebner (2007), Rynes and Gephardt (2004), and Smith and Hitt (2005). Clayton Christensen's 2003 article in Harvard Business Review with Michael Raynor also provides a succinct explanation of the value of theory and how it is developed, tested, and improved. A submission to APJM should have a primary focus on theory: theory building, theory testing, or theory improvement. ${ }^{4}$ When an editor or reviewer tells an author that his or her paper "lacks theory," it may be that the paper's research focus is only on management practice or describing a case while failing to provide good theory justification and contribution to theory (Ahlstrom, 2010c; Sutton \& Staw, 1995).

\section{On contributions}

An author should also be sure that the submission makes a meaningful contribution to the literature (Ahlstrom, 2010b; Rynes et al., 2005). Just testing what is already well known without providing clear contributions or some new information is likely to lead to rejection in good academic journals (e.g., Kilduff, 2007; Rynes, 2002; Rynes et al., 2005). Additional guidance on contributing to theory is available in a number of sources in the management literature (e.g., Colquitt \& Ireland, 2009; Corley \& Gioia, 2011; Van de Ven, 2007; Whetten, 1989). For contributions to practice, some helpful works include Bartunek and Rynes (2010), Christensen and Raynor (2003), and Peng and Dess (2010). For some good discussion and examples of empirical contributions (as well as other contributions) see Meyer, Estrin, Bhaumik, and Peng (2009), as well as Peng, Li, Xie, and Su (2010), Rynes et al. (2005), and Su, Tsang, and Peng (2009). Authors should remember that their contributions, particularly those to theory and practice, should provide actionable insights for interested readers. More will be written on important topics such as contributions and the literature review in upcoming issues of $A P J M$ " (cf. Edmondson \& McManus, 2007).

\section{References}

Abbott, A. 2004. Methods of discovery: Heuristics for the social sciences. New York: W.W. Norton \& Co. Ahlstrom, D. 2010a. Publishing in the Asia Pacific Journal of Management. Asia Pacific Journal of Management, 27(1): 1-8.

Ahlstrom, D. 2010b. Clearing the first hurdle at the Asia Pacific Journal of Management. Asia Pacific Journal of Management, 27(2): 171-177.

Ahlstrom, D. 2010c. Avoiding common missteps: Writing papers suitable for the Asia Pacific Journal of Management. Asia Pacific Journal of Management, 27(4): 583-586.

Ahlstrom, D. 2011a. On the aims and scope of the Asia Pacific Journal of Management: What does APJM really seek to publish?. Asia Pacific Journal of Management, 28(2): 215-219.

Ahlstrom, D. 2011b. A checklist for prospective authors of Asia Pacific Journal of Management. Asia Pacific Journal of Management, 28(3): 449-452.

\footnotetext{
${ }^{4}$ It bears repeating that although theory is very important at $A P J M$, it is not the only contribution that a paper should make. Submissions should suggest contributions to practice, and if data are collected, some empirical contribution should be provided. Others include contributions to research design and methods (Ahlstrom et al., 2009; Peng, 2004).
} 
Ahlstrom, D., Lamond, D., \& Ding, Z. 2009. Reexamining some management lessons from military history. Asia Pacific Journal of Management, 26(4): 617-642.

Bartunek, J. M., \& Rynes, S. L. 2010. The construction and contributions of implications for practice: What's in them and what might they offer?. Academy of Management Learning \& Education, 9: 100117.

Bhagat, R. S., McDevitt, A. S., \& McDevitt, I. 2010. On improving the robustness of Asian management theories: Theoretical anchors in the era of globalization. Asia Pacific Journal of Management, 27(2): 179-192.

Bono, J. E., \& McNamara, G. 2011. From the editors: Publishing in AMJ-Part 2: Research design. Academy of Management Journal, 54(4): 657-660.

Carney, M., Gedajlovic, E., \& Yang, X. 2009. Varieties of Asian capitalism: Toward an institutional theory of Asian enterprise. Asia Pacific Journal of Management, 26(3): 361-380.

Christensen, C. M., \& Carlile, P. R. 2009. Course research: Using the case method to build and teach management theory. Academy of Management Learning \& Education, 8(2): 240-251.

Christensen, C. M., \& Raynor, M. E. 2003. Why hard-nosed executives should care about management theory. Harvard Business Review, 81(9): 66-74.

Christensen, C. M. 2006. The ongoing process of building a theory of disruption. Journal of Product Innovation Management, 23(1): 39-55.

Colquitt, J. A., \& George, G. 2011. From the editors. Publishing in AMJ-Part 1: Topic choice. Academy of Management Journal, 54(3): 432-435.

Colquitt, J. A., \& Ireland, R. D. 2009. From the editors: Taking the mystery out of AMJ's reviewer evaluation form. Academy of Management Journal, 52(2): 224-228.

Corley, K. G., \& Gioia, D. A. 2011. Building theory about theory building: What constitutes a theoretical contribution?. Academy of Management Review, 36(1): 12-32.

Creswell, J.W. 2008. Research design: Qualitative, quantitative, and mixed methods approaches. Thousand Oaks, CA: Sage Publications (3rd edition).

Cummings, L. L., \& Frost, P. J. (Eds.). 1985. Publishing in the organizational sciences. Homewood, IL: Irwin.

Cummings, L. L., \& Frost, P. J. (Eds.). 1995. Publishing in the organizational sciences, 2nd ed. Thousand Oaks, CA: Sage.

Edmondson, A. C., \& McManus, S. E. 2007. Methodological fit in management field research. Academy of Management Review, 32(4): 1155-1179.

Eisenhardt, K. M., \& Graebner, M. E. 2007. Theory building from cases: Opportunities and challenges. Academy of Management Journal, 50(1): 25-32.

Fang, T. 2010. Asian management research needs more self-confidence: reflection on Hofstede (2007) and beyond. Asia Pacific Journal of Management., 27(1): 155-170.

Flyvbjerg, B. 2006. Five misunderstandings about case-study research. Qualitative Inquiry, 12(2): 219245.

Hayton, J. C., George, G., \& Zahra, S. A. 2002. National culture and entrepreneurship: A review of behavioral research. Entrepreneurship: Theory \& Practice., 26(4): 33-52.

Huff, A. S. 1999. Writing for scholarly publication. Thousand Oaks, CA: Sage.

Huff, A. S. 2008. Designing research for publication. Thousand Oaks, CA: Sage.

Ismail, K. M., \& Ford, D. L. 2010. Organizational leadership in Central Asia and the Caucasus: Research considerations and directions. Asia Pacific Journal of Management, 27(2): 321-340.

Kilduff, M. 2007. Editor's comments: The top ten reasons why your paper might not be sent out for review. Academy of Management Review, 32: 700-702.

Locke, E. A., \& Latham, G. P. 2009. Has goal setting gone wild, or have its attackers abandoned good scholarship?. Academy of Management Perspectives, 23(1): 17-23.

Machi, A., \& McEvoy, B. T. 2008. The literature review: Six steps to success. Thousand Oaks, CA: Corwin Press.

Meyer, K. E., Estrin, S., Bhaumik, S. K., \& Peng, M. W. 2009. Institutions, resources, and entry strategies in emerging economies. Strategic Management Journal, 30: 61-80.

Peng, M. W. 2004. Outside directors and firm performance during institutional transitions. Strategic Management Journal, 25: 453-471.

Peng, M. W., \& Dess, G. G. 2010. In the spirit of scholarship. Academy of Management Learning \& Education, 9(2): 282-298.

Peng, M. W., Li, Y., Xie, E., \& Su, Z. 2010. CEO duality, organizational slack, and firm performance in China. Asia Pacific Journal of Management, 27(4): 611-624. 
Rynes, S. L. 2002. From the editors: Some reflections on contribution. Academy of Management Journal, 45: $311-313$.

Rynes, S., \& Gephart, R. P. 2004. From the editors: Qualitative research and the "Academy of Management Journal". Academy of Management Journal, 47(4): 454-462.

Rynes, S. L., Hillman, A., Ireland, R. D., Kirkman, B., Miller, C. C., Rajagopalan, N., \& Shapiro, D. 2005. From the editors: Everything you've always wanted to know about $A M J$ (but may have been afraid to ask). Academy of Management Journal, 48(5): 732-737.

Shane, S. A. 2008. The illusions of entrepreneurship: The costly myths that entrepreneurs, investors, and policy makers live by. New Haven, CT: Yale University Press.

Siggelkow, N. 2007. Persuasion with case studies. Academy of Management Journal, 50(1): 20-24.

Smith, K. G., \& Hitt, M. A. (Eds.). 2005. Great minds in management: The process of theory development. New York: Oxford University Press.

Stevens, C. E., \& Cooper, J. T. 2010. A behavioral theory of governments' ability to make credible commitments to firms: The case of the East Asian paradox. Asia Pacific Journal of Management, 27 (4): 587-610.

Su, Y.-S., Tsang, E. W. K., \& Peng, M. W. 2009. How do internal capabilities and external partnerships affect innovativeness?. Asia Pacific Journal of Management, 26(2): 309-331.

Suddaby, R. 2006. From the editors: What grounded theory is not. Academy of Management Journal, 49 (4): 633-642.

Sutton, R. I., \& Staw, B. M. 1995. What theory is not. Administrative Science Quarterly, 40: 371-384.

Van de Ven, A. H. 2007. Engaged scholarship: A guide for organizational and social research. Oxford: Oxford University Press.

Whetten, D. A. 1989. What constitutes a theoretical contribution?. Academy of Management Review, 14 (4): 490-495.

Yin, R. K. 2009. Case study research: Design and methods. Los Angeles, CA: Sage.

David Ahlstrom ( $\mathrm{PhD}$, New York University) is a professor at The Chinese University of Hong Kong. His research interests include managing in Asia, innovation and entrepreneurship, and management history. Professor Ahlstrom has published over 70 peer-reviewed articles in journals such as the Strategic Management Journal, Academy of Management Review, Journal of International Business Studies, Academy of Management Perspectives, Journal of Business Venturing, and Asia Pacific Journal of Management. He also co-authored the textbook International Management: Strategy and Culture in the Emerging World and guest edited two Special Issues of Entrepreneurship: Theory \& Practice. Professor Ahlstrom has also guest edited two Special Issues of APJM: Turnaround in Asia in 2004 and Managing in Ethnic Chinese Communities in 2010, and was Senior Editor of APJM during 2007-2009, before serving as its Editor-in-Chief. 